\title{
Chemical Composition and Trypanocidal Activity of the Essential Oils from Hedychium coronarium J. Koenig (Zingiberaceae)
}

\author{
Danilo Fernando Rodrigues, ${ }^{1,2}$ Angela María Arenas Velásquez, ${ }^{1,2}$ \\ Carlos Cavaleiro, ${ }^{3}$ Lígia Salgueiro, ${ }^{3}$ Gilmárcio Zimmermann Martins, \\ Nathália Oliveira Magalhães, ${ }^{4}$ Maria Bernadete Gonçalves Martins, ${ }^{5}$ \\ Regina Maria Barretto Cicarelli, ${ }^{1,2}$ and Raquel Regina Duarte Moreira ${ }^{4}$ \\ ${ }^{1}$ Department of Biological Sciences, School of Pharmaceutical Sciences of Araraquara, UNESP, São Paulo State University, \\ 14801-902 Araraquara, SP, Brazil \\ ${ }^{2}$ Institute of Chemistry, UNESP, São Paulo State University, 14800-900 Araraquara, SP, Brazil \\ ${ }^{3}$ Center of Pharmaceutical Studies, Faculty of Pharmacy, University of Coimbra, 3000-548 Coimbra, Portugal \\ ${ }^{4}$ Department of Natural Active Principles and Toxicology, School of Pharmaceutical Sciences of Araraquara, UNESP, \\ São Paulo State University, 14801-902 Araraquara, SP, Brazil \\ ${ }^{5}$ UNESP, São Paulo State University, Coast Campus, 11330-900 São Vicente, SP, Brazil
}

Correspondence should be addressed to Danilo Fernando Rodrigues; danilo_frodrigues@hotmail.com and Raquel Regina Duarte Moreira; moreirar@fcfar.unesp.br

Received 31 May 2013; Accepted 20 June 2013

Academic Editors: M. A. De Souza and H. Hisaeda

Copyright (c) 2013 Danilo Fernando Rodrigues et al. This is an open access article distributed under the Creative Commons Attribution License, which permits unrestricted use, distribution, and reproduction in any medium, provided the original work is properly cited.

\begin{abstract}
The composition of the essential oils (EO) from leaves and rhizomes of Hedychium coronarium was analyzed both by gas chromatography and gas chromatography-mass spectroscopy. Thirty and thirty-nine compounds were identified, respectively, in the oils from leaves and rhizomes, representing $88 \%$ and $86.1 \%$ of the whole compositions. Caryophyllene oxide is the major component in rhizomes while 1,8-cineole predominates in leaves oil. Essential oils and major components were tested for trypanocidal activity using procyclic forms of Trypanosoma brucei (427 and 29-13 strains). The cytotoxicity index $\left(\mathrm{CI}_{50}\right)$, using the MTT colorimetric method, showed that essential oils and 1,8-cineole were inactive $\left(>100 \mu \mathrm{g} \cdot \mathrm{mL}^{-1}\right.$. Nevertheless, caryophyllene oxide revealed a remarkable activity against both $T$. brucei strains $\left(\mathrm{CI}_{50}=65.77 \mu \mathrm{g} \cdot \mathrm{mL}^{-1}\right.$ and $24.53 \mu \mathrm{g} \cdot \mathrm{mL} L^{-1}$, resp.), and the synergism between caryophyllene oxide plus pentamidine $(1: 1, \mathrm{v} / \mathrm{v})$ highly increased the trypanocidal activity $\left(<1.0 \mu \mathrm{g} \cdot \mathrm{mL}^{-1}\right)$.
\end{abstract}

\section{Introduction}

As part of our ongoing research, exploring the potential of the Brazilian plant biodiversity as a source of bioactive compounds, we looked now for the trypanocidal proprieties of the essential oils isolated from Hedychium coronarium J. Koenig (Zingiberaceae). H. coronarium is a monocotyledon from the tropical Asia, well adapted in South-America, especially in Brazil, where it is popularly named "lírio-dobrejo" or "gengibre-branco" [1-3]. It is an invasive weed used by locals for healing bruise injuries, infections, sore throats, rheumatism, diabetes, headaches, and severe pain [1-3].

Human African trypanosomiasis (HAT) or sleeping sickness is caused by the parasite Trypanosoma brucei, a flagellate protozoan transmitted by flies of Glossina genus, known as tsetse flies. Trypanosome has two hosts-the insect vector and mammalian host [4]. Due to the great differences among the hosts, the parasite undergoes complex changes during the life cycle that facilitate its survival inside the insect gut or inside the mammalian bloodstream [5]. It also features a unique 
TABLE 1: Composition of the volatile oils of leaves and rhizomes of Hedychium coronarium from Brazil.

\begin{tabular}{|c|c|c|c|c|}
\hline \multirow{2}{*}{$\mathrm{RI}^{\mathrm{a}}$} & \multirow{2}{*}{$\mathrm{RI}^{\mathrm{b}}$} & \multirow{2}{*}{ Compound } & \multicolumn{2}{|c|}{ Percent in samples (\%) } \\
\hline & & & Leaves & Rhizome \\
\hline 921 & n.d. & $\alpha$-Thujene & - & 0.1 \\
\hline 928 & 1025 & $\alpha$-Pinene & 0.2 & 1.9 \\
\hline 941 & 1072 & Camphene & - & 0.3 \\
\hline 963 & 1124 & Sabinene & $\mathrm{t}$ & 0.2 \\
\hline 968 & 1115 & $\beta$-Pinene & 1.1 & 11.7 \\
\hline 980 & 1159 & Myrcene & - & 0.4 \\
\hline 997 & 1167 & $\alpha$-Phellandrene & - & 0.1 \\
\hline 1005 & 1150 & $\delta$-3-Carene & - & 0.2 \\
\hline 1008 & n.d. & $\alpha$-Terpinene & $\mathrm{t}$ & - \\
\hline 1012 & 1272 & p-Cymene & 0.2 & 1.4 \\
\hline 1019 & 1204 & Limonene $^{*}$ & $\mathrm{t}$ & 2.4 \\
\hline 1020 & 1212 & 1,8 -Cineole ${ }^{*}$ & 0.7 & 31.7 \\
\hline 1025 & n.d. & $Z$-Ocimene & - & 0.3 \\
\hline 1046 & 1246 & $\gamma$-Terpinene & - & 0.5 \\
\hline 1051 & 1457 & E-Sabinene hydrate & - & 0.5 \\
\hline 1077 & 1284 & Terpinolene & - & 0.3 \\
\hline 1082 & 1542 & Z-Sabinene hydrate & 0.2 & 0.4 \\
\hline 1084 & 1539 & Linalool & - & 0.7 \\
\hline 1105 & n.d. & Fenchol & - & 0.2 \\
\hline 1106 & 1488 & $\alpha$-Campholenal & 0.3 & 0.2 \\
\hline 1109 & n.d. & $Z$-p-Menth-2-en-1-ol & - & 0.2 \\
\hline 1119 & 1514 & Camphor & - & 0.1 \\
\hline 1120 & n.d. & Nopinone & $\mathrm{t}$ & - \\
\hline 1122 & 1645 & E-Pinocarveol & 1.3 & 0.4 \\
\hline 1123 & 1645 & $Z$-Verbenol & - & 0.3 \\
\hline 1129 & 1668 & E-Verbenol & 0.4 & - \\
\hline 1136 & 1564 & Pinocarvone & 1.3 & 0.4 \\
\hline 1145 & 1691 & Borneol & $\mathrm{t}$ & 3.1 \\
\hline 1160 & 1594 & Terpinene-4-ol & 1.0 & 6.8 \\
\hline 1164 & 1622 & Myrtenal & 1.4 & 0.1 \\
\hline 1171 & 1687 & $\alpha$-Terpineol & 0.6 & 12.0 \\
\hline 1178 & 1780 & Myrtenol & 1.4 & - \\
\hline 1186 & n.d. & E-Piperitol & - & 0.4 \\
\hline 1191 & n.d. & E-Carveol & - & 0.2 \\
\hline 1329 & 1688 & $\alpha$-Terpinyl acetate & - & 1.2 \\
\hline 1403 & 1840 & $\alpha$-Ionone & 0.2 & - \\
\hline 1407 & 1591 & E-Caryophyllene & 12.1 & 1.3 \\
\hline 1440 & 1661 & $\alpha$-Humulene & 0.8 & 0.2 \\
\hline 1446 & 1659 & $E$ - $\beta$-Farnesene & $\mathrm{t}$ & 0.2 \\
\hline 1460 & 1927 & $\beta$-Ionone & 0.6 & - \\
\hline 1469 & n.d. & $\beta$-Selinene & - & 0.2 \\
\hline 1502 & 1752 & $\gamma$-Cadinene & - & 0.4 \\
\hline 1559 & 1971 & Caryophyllene oxide & 43.9 & 1.1 \\
\hline 1569 & 2078 & $\begin{array}{l}\text { Caryophylla-2(12),6(13)- } \\
\text { dien-5-one }\end{array}$ & 0.4 & - \\
\hline 1582 & 2026 & Humulene epoxide II & 2.8 & 0.2 \\
\hline 1607 & 2277 & $\begin{array}{l}\text { Caryophylla-2(12),6(13)- } \\
\text { dien-5-beta-ol }\end{array}$ & 1.8 & - \\
\hline
\end{tabular}

TABle 1: Continued.

\begin{tabular}{|c|c|c|c|c|}
\hline \multirow{2}{*}{$\mathrm{RI}^{\mathrm{a}}$} & \multirow{2}{*}{$\mathrm{RI}^{\mathrm{b}}$} & \multirow{2}{*}{ Compound } & \multicolumn{2}{|c|}{ Percent in samples (\%) } \\
\hline & & & Leaves & Rhizome \\
\hline 1609 & 2283 & $\begin{array}{l}\text { Caryophylla-2(12),6(13)- } \\
\text { dien-5-alpha-ol }\end{array}$ & 7.7 & - \\
\hline 1631 & 2270 & $\begin{array}{l}\text { Caryophylla-2(12),6-dien-5 } \\
\text { alpha-ol }\end{array}$ & 2.0 & - \\
\hline 1645 & 2360 & $\begin{array}{l}\text { Caryophylla-2(12),6-dien-5 } \\
\text { beta-ol }\end{array}$ & 5.6 & - \\
\hline \multirow[t]{7}{*}{2091} & n.d. & Coronarin $\mathrm{E}^{\#}$ & - & 14.1 \\
\hline & & Monoterpene hydrocarbons & 1.5 & 19.5 \\
\hline & & $\begin{array}{l}\text { Oxygen containing } \\
\text { monoterpenes }\end{array}$ & 8.6 & 58.8 \\
\hline & & Sesquiterpene hydrocarbons & 12.9 & 2.4 \\
\hline & & $\begin{array}{l}\text { Oxygen containing } \\
\text { sesquiterpenes }\end{array}$ & 64.2 & 1.3 \\
\hline & & Other compounds & 0.8 & 14.1 \\
\hline & & Total identified & 88.0 & 86.1 \\
\hline
\end{tabular}

Compounds listed in the order of their elution on the SPB-1 column; $t$ :

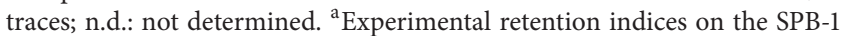
column relative to $\mathrm{C} 8-\mathrm{C} 24 n$-alkanes. ${ }^{\mathrm{b}}$ Experimental retention indices on the Supelcowax-10 column relative to C8 to C24 $n$-alkanes. ${ }^{*}$ Quantification based on peak areas from Supelcowax-10 chromatogram. " Identity proposed on the basis of mass spectra: $\mathrm{m} / z$ (relative intensity) $284\left[\mathrm{M}^{+}\right](78), 147(100)$, 81 (45), 55 (39), 41 (34), 91 (34), 95 (33), 137 (31), 69 (25), 77 (24), 131 (23), 148 (23), 117 (22), 129 (22), 79 (21), 115 (21).

and notable variable surface glycoprotein (VSG) coat that protects the parasite from the host's immune system. These characteristics contribute to the extraordinary resistance of the trypanosome which contributes to the difficult or ineffective therapies of trypanosomiasis [6].

There are several therapeutic approaches for the disease, however, not entirely efficient, causing severe adverse effects and leading to resistance. Patients usually need to be examined in subsequent years after treatments to certify that parasites were deleted and no resistant strains overcame [7]. The treatment with pentamidine is assumed to be the most effective in the acute infection but it can cause allergic and toxic side effects, most commonly affecting pancreas, with serious hypoglycemia, which, in part, depends on the daily and/or cumulative dose. In cases of brain impairment caused by the parasite, the condition may be irreversible [8]. Thus, there is an urgent need for the development of new effective and safe therapies for trypanosomiasis.

Aiming at developing of novel drugs, natural products emerge as good alternatives for the search of hits and new leading compounds. The ethanolic extract of Hedychium coronarium from the Yanesha (Peru) was proved to be active $\left(\mathrm{IC}_{50}<10 \mu \mathrm{g} / \mathrm{mL}\right)$ on Leishmania amazonensis amastigote stages [9]. Essential oils and essential oil constituents have been studied, in the last years, for their activity on several pathogenic protozoan as Giardia sp. [10-12], Leishmania sp. [13, 14], and Trypanosoma sp. [15-20]. Mechanisms for such activities were not definitively elucidated. However, the impairment of membranes and other protozoa structures and the interference in the redox balance, targeting crucial metabolic pathways and leading to autophagic processes, 
were suggested as consistent mechanisms to explain the activity of essential oils and some of their constituents.

The chemical composition of the essential oils from leaves and rhizomes of $H$. coronarium was established and the trypanocidal effects of the oils and their major components, were tested on procyclic forms of Trypanosoma brucei ( 427 and 29-13 strains). As far as we know, this is the first study dealing with the activity of the essential oils of $H$. coronarium and its constituents against T. brucei.

\section{Experimental Section}

2.1. Plant Material. Leaves and rhizomes of $H$. coronarium were collected in the Ecological Station "Juréia-Itatins" by Dr. Maria Bernadette G. Martins on March 15, 2011, and the specimens were identified by Dr. Vinicius Castro Souza. Voucher specimens were deposited in the Herbarium of the College of Agriculture, with ESA/USP having registeration number 93272 ESA.

2.2. Preparation of Essential Oils. Leaves and rhizomes were submitted to gentle air drying at room temperature and then processed independently, leaves were coarsely divided, and rhizomes were cut and crushed. Essential oils were then prepared by hydrodistillation of plant material for 4 hours, using a Clevenger apparatus. Oils were stored at the dark at $4^{\circ} \mathrm{C}$ until used.

Caryophyllene oxide and 1.8-cineole were acquired from Sigma-Aldrich.

2.3. Essential Oil Analysis. Compositions of essential oils were accessed by means of gas chromatography (GC) and gas chromatography-mass spectroscopy (GC/MS). Analytical GC was carried out in a Hewlett-Packard 6890 (Agilent Technologies, Palo Alto, CA, USA) gas chromatograph with HP GC ChemStation Rev. A.05.04 data handling system, equipped with a single injector and two flame ionization detection (FID) systems. The Graphpak divider (Agilent Technologies, part no. 5021-7148) was used for simultaneous sampling to two Supelco (Supelco, Bellefonte, PA, USA) fused silica capillary columns with different stationary phases: SPB-1 (polydimethylsiloxane $30 \mathrm{~m} \times 0.20 \mathrm{~mm}$ id, film thickness $0.20 \mu \mathrm{m}$ ) and Supelcowax-10 (polyethyleneglycol $30 \mathrm{~m}$ $\times 0.20 \mathrm{~mm}$ id, film thickness $0.20 \mu \mathrm{m})$. Oven temperature program is $70-220^{\circ} \mathrm{C}\left(3^{\circ} \mathrm{C} \cdot \mathrm{min}^{-1}\right), 220^{\circ} \mathrm{C}(15 \mathrm{~min})$, with injector temperature: $250^{\circ} \mathrm{C}$, carrier gas: helium, adjusted to a linear velocity of $30 \mathrm{~cm} \cdot \mathrm{s}^{-1}$; splitting ratio $1: 40$; detectors temperature: $250^{\circ} \mathrm{C}$. GC-MS was carried out in a HewlettPackard 6890 gas chromatograph fitted with an HP1-fused silica column (polydimethylsiloxane $30 \mathrm{~m} \times 0.25 \mathrm{~mm}$ i.d., $0.25 \mu \mathrm{m}$ film thickness) interfaced with a Hewlett-Packard 5973 mass selective detector (Agilent Technologies) operated by HP Enhanced ChemStation software, version A.03.00. GC parameters are described above, with interface temperature: $250^{\circ} \mathrm{C}$, MS source temperature: $230^{\circ} \mathrm{C}$, MS quadrupole temperature: $150^{\circ} \mathrm{C}$, ionization energy: $70 \mathrm{eV}$, ionization current: $60 \mathrm{~mA}$, scan range: $35-350$ units, and scans $\cdot \mathrm{s}^{-1}: 4.51$.

Essential oil components were identified by their retention indices on both SPB-1 and Supelcowax-10 columns and from their mass spectra. Retention indices, calculated by linear interpolation relative to retention times of C8-C23 of $n$-alkanes, were compared with those of reference samples included in the Center for Pharmaceutical Studies, Faculty of Pharmacy, University of Coimbra database. Acquired mass spectra were compared with reference spectra from laboratory database, Wiley/NIST library [21], and literature data $[22,23]$. Relative amounts of individual components were calculated based on GC raw data areas without FID response factor correction.

2.4. Trypanocidal Activity. Procyclic forms of T. brucei strains-427 [24] and 29-13 [25] —were grown at $28^{\circ} \mathrm{C}$ in SDM-79 medium [26] containing 10\% fetal bovine serum (Gibco), penicillin (Sigma-Aldrich), and streptomycin (Sigma-Aldrich). Procyclic forms cultures were carried out to obtain the exponential growth phase $\left(1 \times 10^{6}\right.$ parasites $\left./ \mathrm{mL}\right)$. Log phase procyclic parasites were frozen at $-80^{\circ} \mathrm{C}$ with $10 \%$ glycerol for storage.

2.5. MTT Colorimetric Assay of T. brucei Strains. Procyclic forms of T. brucei (427 and 29-13 strains) were incubated for 24 hours with the essential oils or with pure compounds for determination of cytotoxicity index $\left(\mathrm{CI}_{50}\right)$ accessed by the MTT colorimetric assay. This assay is based on the determination of the ability of living cells to reduce 3-(4,5-dimethyl2-thiazolyl)-2,5-diphenyl-2H-tetrazolium bromide (MTT) to the corresponding formazan. Assays were performed in 96well plates, according to the methodology described by Mosmann (1983) [27] and modified by Cotinguiba and colaborators (2009) [28]. Each test was made in triplicate. The essential oils and isolated compounds were solubilized in DMSO (dimethyl sulfoxide) (Synth), and at the time of use dilutions were made in different concentrations using SDM79 medium; the final concentration of the solutions reached $3 \%$ DMSO, which does not affect the viability of the parasites. Pentamidine and SDM-79 medium were used as positive and negative controls, respectively.

\section{Results and Discussion}

The compositions of the essential oils from leaves and from rhizomes of $H$. coronarium are described in Table 1 , where compounds are listed in the order of their retention on the SBP-1 column (Figures 1 and 2).

Thirty-nine components were identified in the oil from rhizomes, representing $86.1 \%$ of the whole composition. Monoterpene hydrocarbons and oxygen containing monoterpenes prevail in the rhizomes oil, with 1,8-cineole (31.7\%), $\alpha$-terpineol (12.0\%), $\beta$-pinene (11.0\%), and terpinen4 -ol $(6.8 \%)$ as the major constituents. The occurrence of these compounds was previously described [29-31]. Additionally, the labdane diterpenoid coronarin $\mathrm{E}$ was also found at the concentration of $14.1 \%$. The occurrence of diterpenoids in the composition of the rhizomes oil of $H$. coronarium was never reported.

In the leaves oil, thirty components were identified, representing $88 \%$ of the whole composition. The oil is mainly 
TIC: HEDCORF.D

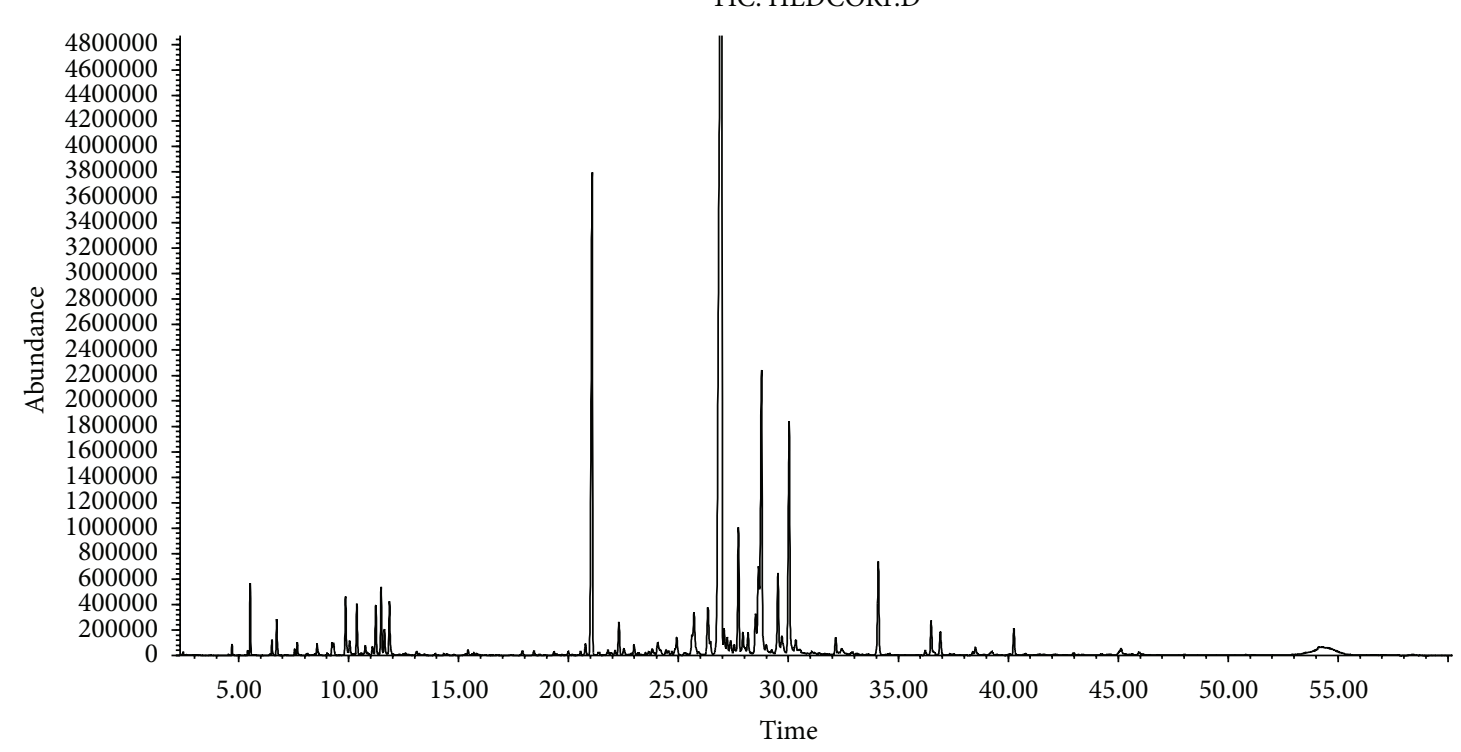

FIGURE 1: Chromatogram of Hedychium coronarium leaves essential oil (SBP-1 column).

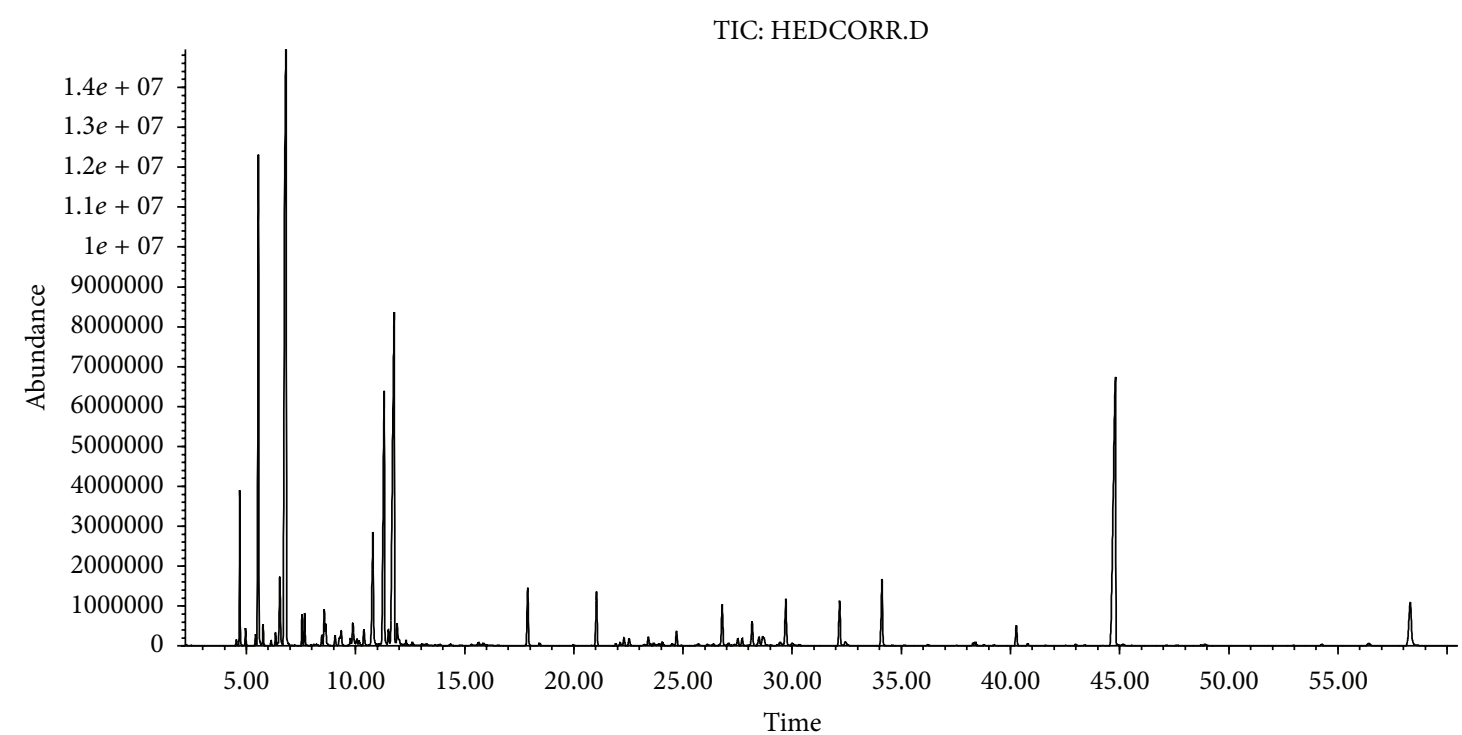

FIGURE 2: Chromatogram of Hedychium coronarium rhizomes essential oil (SBP-1 column).

composed by sesquiterpenoids, particularly caryophyllene derivatives $(73.5 \%)$, with caryophyllene oxide $(43.9 \%), E$ caryophyllene (12.1\%), caryophylladienol I (7.7\%), caryophyllenol II (5.6\%), caryophyllenol I (2.0\%), and caryophylladienol II $(1.8 \%)$ as the most representative. This composition is different from those reported by Ali et al. (2002) [30] and Dos Santos et al. (2010) [29]. Ali et al. (2002) describe plants growing in Fiji islands composed by monoterpenes $(\beta$ pinene, $53.6 \%$ ) and sesquiterpenes ( $\beta$-caryophyllene, $17.7 \%$ ); Dos Santos et al. (2010) report $\beta$-caryophyllene $(43.0 \%)$, caryophyllene oxide (12.1\%), and $\alpha$-humulene $(2.2 \%)$ as the major constituents of an oil from plants growing in Brazil.
Table 2 summarizes the results of the trypanocidal effects of the essential oils and pure compounds.

Cytotoxicity index $\left(\mathrm{CI}_{50}\right)$ values of the crude essential oils $\left(>100 \mu \mathrm{g} \cdot \mathrm{mL}^{-1}\right)$, as well as of 1,8 -cineole, the major constituent of the rhizomes oil, indicated no trypanocidal activity $\left(\mathrm{CI}_{50}\right.$ value of pentamidine, used as positive control, was estimated as $2.19 \mu \mathrm{g} \cdot \mathrm{mL}^{-1}$ ). Nevertheless, caryophyllene oxide, the major constituent of the essential oil from leaves, revealed a remarkable activity against both $T$. brucei strains, 427 $\left(\mathrm{CI}_{50}=65.77 \mu \mathrm{g} \cdot \mathrm{mL}^{-1}\right)$ and $29-13\left(\mathrm{CI}_{50}=24.53 \mu \mathrm{g} \cdot \mathrm{mL}^{-1}\right)$. The mixture caryophyllene oxide, pentamidine $(1: 1, \mathrm{v} / \mathrm{v})$, revealed a stronger activity $\left(\mathrm{CI}_{50}=<1.0 \mu \mathrm{g} \cdot \mathrm{mL}^{-1}\right)$, similar 
TABLE 2: In vitro trypanocidal activity of essential oils and major components of Hedychium coronarium against Trypanosoma brucei procyclic forms.

\begin{tabular}{lcc}
\hline Compounds & $\begin{array}{c}\text { T. brucei }(427 \text { strain) } \\
\mu \mathrm{g} \cdot \mathrm{mL}^{-1}\end{array}$ & $\begin{array}{c}\text { T. brucei }(29-13 \text { strain }) \\
\mu \mathrm{g} \cdot \mathrm{mL}^{-1}\end{array}$ \\
\hline $\begin{array}{l}\text { Essential oil from } \\
\text { leaves }\end{array}$ & $>100$ & $>100$ \\
$\begin{array}{l}\text { Essential oil from } \\
\text { rhizomes }\end{array}$ & $>100$ & $>100$ \\
1,8 -Cineol & $>100$ & $>100$ \\
$\begin{array}{l}\text { Caryophyllene oxide } \\
\text { Caryophyllene }\end{array}$ & 65.77 & 24.53 \\
$\begin{array}{l}\text { oxide + pentamidine } \\
\text { Pentamidine }\end{array}$ & $<1.0$ & $<1.0$ \\
\hline
\end{tabular}

to both Trypanosoma strains, indicating a probable synergic effect. Caryophyllene oxide was previously recognised as one of the key ingredients for the activity of the hexane extract of Serjania yucatanensis against trypomastigotes of Trypanosoma cruzi [32]. Furthermore, cytotoxic effects of caryophyllene oxide on several cellular models due to the inhibition of the mitochondrial electron transport chain [33] and apoptosis induction [34] can also explain our results.

\section{Conclusions}

The compositions of the essential oils from leaves and from rhizomes of $H$. coronarium from Brazil were established. Despite the lack or the feeble trypanocidal activity of these essential oils, the major constituent of the leaves oil, caryophyllene oxide, revealed remarkable potential trypanocidal activity. This activity was strain dependent since it is higher on T. brucei 29-13. Interestingly, a potential synergism between caryophyllene oxide and pentamidine was demonstrated in this study. This can be an issue for further studies using natural compounds as an alternative treatment of chronic parasite diseases.

\section{Conflict of Interests}

The authors declare no conflict of interests.

\section{Acknowledgments}

The authors are grateful to Fundação para a Ciência e Tecnologia (FCT), POCI 2010/FEDER, Fundação para o Desenvolvimento da Unesp (FUNDUNESP), and Coordenação de Aperfeiçoamento de Pessoal de Nível Superior (CAPES) for financial support.

\section{References}

[1] O. S. Couto and R. M. S. Cordeiro, Manual de reconhecimento de espécies vegetais da restinga do Estado de São Paulo, Centro de Editoração da Secretaria do Meio Ambiente, Departamento Estadual de Proteção de recursos naturais-DEPRN, São Paulo, Brazil, 2005.
[2] V. A. Facundo and L. S. Moreira, "Estudo fitoquímico e farmacológico dos constituintes fixos e voláteis de Hedychium coronarium J. Koen. (Zingiberaceae)," in Anais do XLV Congresso Brasileiro de Química. Belém, Brasil, 2005, p. 45, Associação Brasileira de Química, São Paulo, Brazil.

[3] M. B. G. Martins, A. L. C. Caravante, B. Appezzato-DaGlória, M. K. M. Soares, R. R. D. Moreira, and L. E. Santos, "Caracterização anatômica e fitoquímica de folhas e rizomas de Hedychium coronarium J. König (Zingiberaceae)," Revista Brasileira de Plantas Medicinais, vol. 12, pp. 179-187, 2010.

[4] R. Brun and J. Blum, "Human African trypanosomiasis," Infectious Disease Clinics of North America, vol. 26, pp. 261-273, 2012.

[5] M. P. Barrett, R. J. S. Burchmore, A. Stich et al., "The trypanosomiases," The Lancet, vol. 362, no. 9394, pp. 1469-1480, 2003.

[6] E. Pays, S. Lips, D. Nolan, L. Vanhamme, and D. Pérez-Morga, "The VSG expression sites of Trypanosoma brucei: multipurpose tools for the adaptation of the parasite to mammalian hosts," Molecular and Biochemical Parasitology, vol. 114, no. 1, pp. 1-16, 2001.

[7] V. Delespaux and H. P. de Koning, "Drugs and drug resistance in African trypanosomiasis," Drug Resistance Updates, vol. 10, no. 1-2, pp. 30-50, 2007.

[8] R. T. Jacobs, B. Nare, and M. A. Phillips, "State of the art in African trypanosome drug discovery," Current Topics in Medicinal Chemistry, vol. 11, no. 10, pp. 1255-1274, 2011.

[9] C. Valadeau, A. Pabon, E. Deharo et al., "Medicinal plants from the Yanesha (Peru): evaluation of the leishmanicidal and antimalarial activity of selected extracts," Journal of Ethnopharmacology, vol. 123, no. 3, pp. 413-422, 2009.

[10] M. Machado, M. D. C. Sousa, L. Salgueiro, and C. Cavaleiro, "Effects of essential oils on the growth of Giardia lamblia trophozoites," Natural Product Communications, vol. 5, no. 1, pp. 137-141, 2010.

[11] M. Machado, A. M. Dinis, L. Salgueiro, C. Cavaleiro, J. B. A. Custódio, and M. Do Céu Sousa, "Anti-Giardia activity of phenolic-rich essential oils: effects of Thymbra capitata, Origanum virens, Thymus zygis subsp. sylvestris, and Lippia graveolens on trophozoites growth, viability, adherence, and ultrastructure," Parasitology Research, vol. 106, no. 5, pp. 1205$1215,2010$.

[12] M. Machado, P. Pires, A. M. Dinis et al., "Monoterpenic aldehydes as potential anti-Leishmania agents: activity of Cymbopogon citratus and citral on L. infantum, L. tropica and L. major," Experimental Parasitology, vol. 130, no. 3, pp. 223-231, 2012.

[13] M. Machado, G. Santoro, M. C. Sousa, L. Salgueiro, and C. Cavaleiro, "Activity of essential oils on the growth of Leishmania infantum promastigotes," Flavour and Fragrance Journal, vol. 25, no. 3, pp. 156-160, 2010.

[14] M. Machado, A. M. Dinis, L. Salgueiro, J. B. A. Custódio, C. Cavaleiro, and M. C. Sousa, "Anti-Giardia activity of Syzygium aromaticum essential oil and eugenol: effects on growth, viability, adherence and ultrastructure," Experimental Parasitology, vol. 127, no. 4, pp. 732-739, 2011.

[15] E. V. Costa, L. M. Dutra, P. C. D. L. Nogueira et al., "Essential oil from the leaves of Annona vepretorum: chemical composition and bioactivity," Natural Product Communications, vol. 7, no. 2, pp. 265-266, 2012.

[16] S. Mulyaningsih, M. Youns, M. Z. El-Readi et al., "Biological activity of the essential oil of Kadsura longipedunculata (Schisandraceae) and its major components," Journal of Pharmacy and Pharmacology, vol. 62, no. 8, pp. 1037-1044, 2010. 
[17] G. F. Santoro, M. G. Cardoso, L. G. L. Guimarães, L. Z. Mendonça, and M. J. Soares, "Trypanosoma cruzi: activity of essential oils from Achillea millefolium L., Syzygium aromaticum L. and Ocimum basilicum L. on epimastigotes and trypomastigotes," Experimental Parasitology, vol. 116, no. 3, pp. 283-290, 2007.

[18] G. F. Santoro, M. G. Cardoso, L. G. L. Guimarães, J. M. Freire, and M. J. Soares, "Anti-proliferative effect of the essential oil of Cymbopogon citratus (DC) Stapf (lemongrass) on intracellular amastigotes, bloodstream trypomastigotes and culture epimastigotes of Trypanosoma cruzi (Protozoa: Kinetoplastida)," Parasitology, vol. 134, no. 11, pp. 1649-1656, 2007.

[19] E. Nibret and M. Wink, "Trypanocidal and antileukaemic effects of the essential oils of Hagenia abyssinica, Leonotis ocymifolia, Moringa stenopetala, and their main individual constituents," Phytomedicine, vol. 17, no. 12, pp. 911-920, 2010.

[20] A. R. Borges, J. R. Aires, T. M. Higino et al., "Trypanocidal and cytotoxic activities of essential oils from medicinal plants of Northeast of Brazil," Experimental Parasitology, vol. 132, pp. 123-128, 2012.

[21] Registry, 8th ed. with NIST 05 MS Spectra, Revision 2005 D.06.00. s.l. Agilent Technologies, Wiley, 2007.

[22] R. P. Adams, Identification of Essential Oils Components by Gas Chromatography/Quadrupole Mass Spectroscopy, Allured Publishing Corporation, Carol Stream, Ill, USA, 1995.

[23] D. Joulain and K. A. Koenig, The Atlas of Spectra Data of Sesquiterpene Hydrocarbons, EB Verlag, Hamburg, Germany, 1st edition, 1998.

[24] G. A. M. Cross and J. C. Manning, "Cultivation of Trypanosoma brucei sspp. in semi defined and defined media," Parasitology, vol. 67 , no. 3, pp. 315-331, 1973.

[25] E. Wirtz and C. Clayton, "Inducible gene expression in trypanosomes mediated by a prokaryotic repressor," Science, vol. 268, no. 5214, pp. 1179-1182, 1995.

[26] R. Brun and M. Schonenberger, "Cultivation and in vitro cloning of procyclic culture forms of Trypanosoma brucei in a semi-defined medium. Short communication," Acta Tropica, vol. 36, no. 3, pp. 289-292, 1979.

[27] T. Mosmann, "Rapid colorimetric assay for cellular growth and survival: application to proliferation and cytotoxicity assays," Journal of Immunological Methods, vol. 65, no. 1-2, pp. 55-63, 1983.

[28] F. Cotinguiba, L. O. Regasini, V. Da Silva Bolzani et al., "Piperamides and their derivatives as potential anti-trypanosomal agents," Medicinal Chemistry Research, vol. 18, no. 9, pp. 703711, 2009.

[29] B. C. B. Dos Santos, L. E. S. Barata, F. A. Marques et al., "Composition of leaf and rhizome essential oils of Hedychium coronarium koen. from Brazil," Journal of Essential Oil Research, vol. 22, no. 4, pp. 305-306, 2010.

[30] S. Ali, S. Sotheeswaran, M. Tuiwawa, and R. M. Smith, "Comparison of the composition of the essential oils of Alpinia and Hedychium species-essential oils of Fijian plants, part 1," Journal of Essential Oil Research, vol. 14, no. 6, pp. 409-411, 2002.

[31] B. Joy, A. Rajan, and E. Abraham, "Antimicrobial activity and chemical composition of essential oil from Hedychium coronarium," Phytotherapy Research, vol. 21, no. 5, pp. 439-443, 2007.

[32] G. Polanco-Hernández, F. Escalante-Erosa, K. García-Sosa et al., "Metabolites from the leaf extract of Serjania yucatanensis with trypanocidal activity against Trypanosoma cruzi," Parasitology Research, vol. 111, pp. 451-455, 2012.
[33] L. Monzote, W. Stamberg, K. Staniek, and L. Gille, “Toxic effects of carvacrol, caryophyllene oxide, and ascaridole from essential oil of Chenopodium ambrosioides on mitochondria," Toxicology and Applied Pharmacology, vol. 240, no. 3, pp. 337-347, 2009.

[34] K.-R. Park, D. Nam, H.-M. Yun et al., “ $\beta$-Caryophyllene oxide inhibits growth and induces apoptosis through the suppression of PI3K/AKT/mTOR/S6K1 pathways and ROS-mediated MAPKs activation," Cancer Letters, vol. 312, no. 2, pp. 178-188, 2011. 


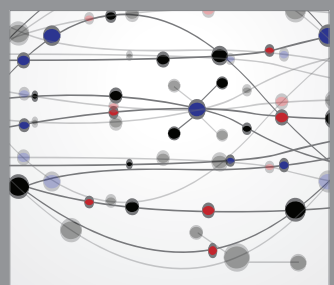

The Scientific World Journal
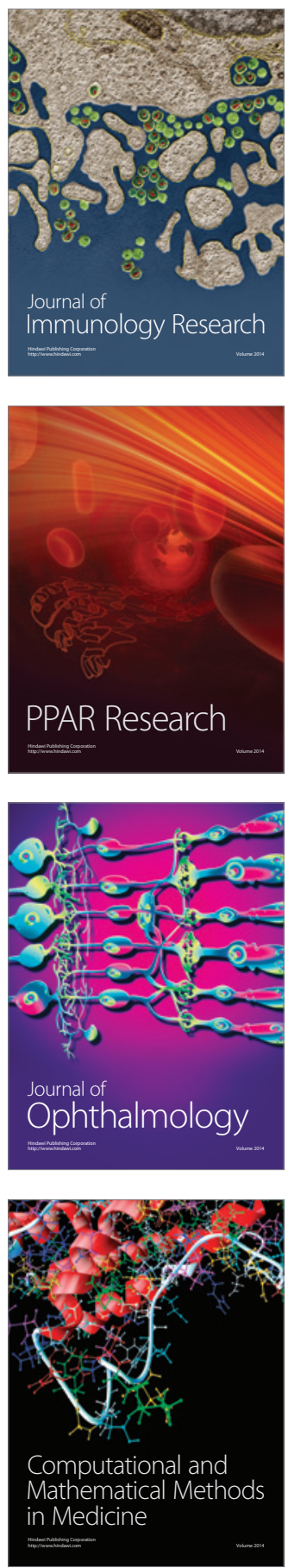

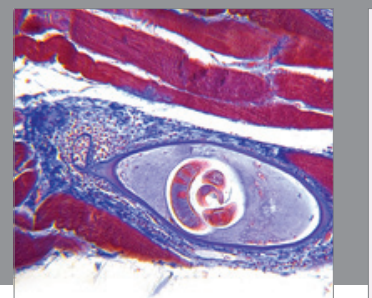

Gastroenterology

Research and Practice
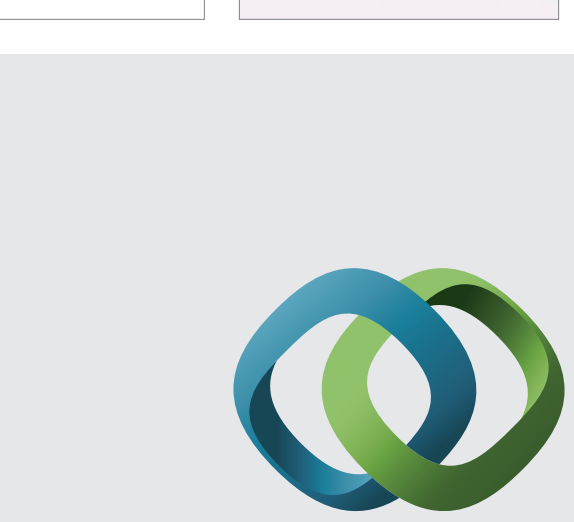

\section{Hindawi}

Submit your manuscripts at

http://www.hindawi.com
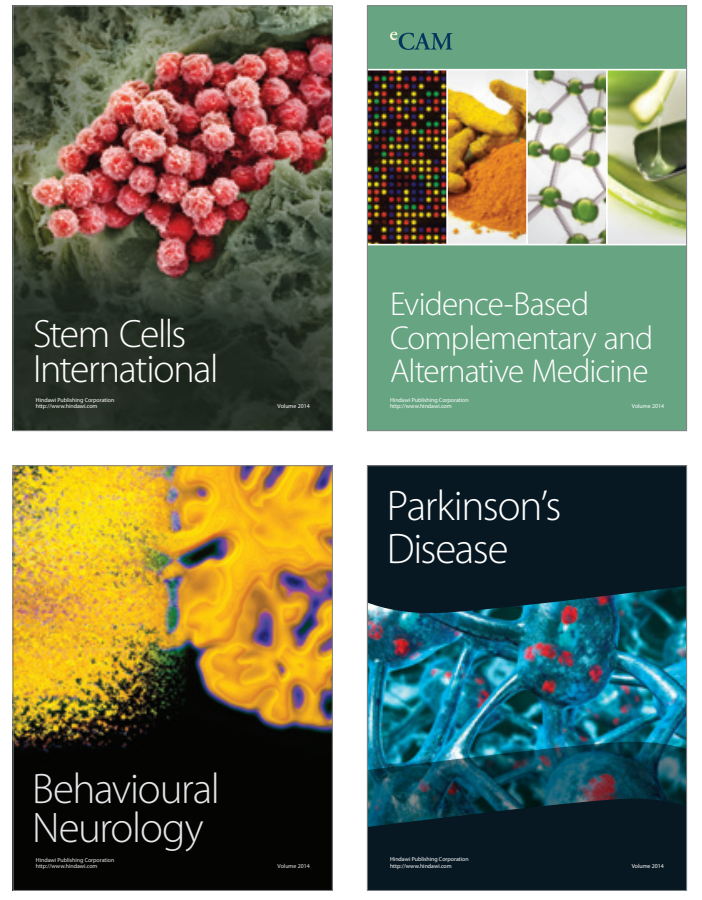
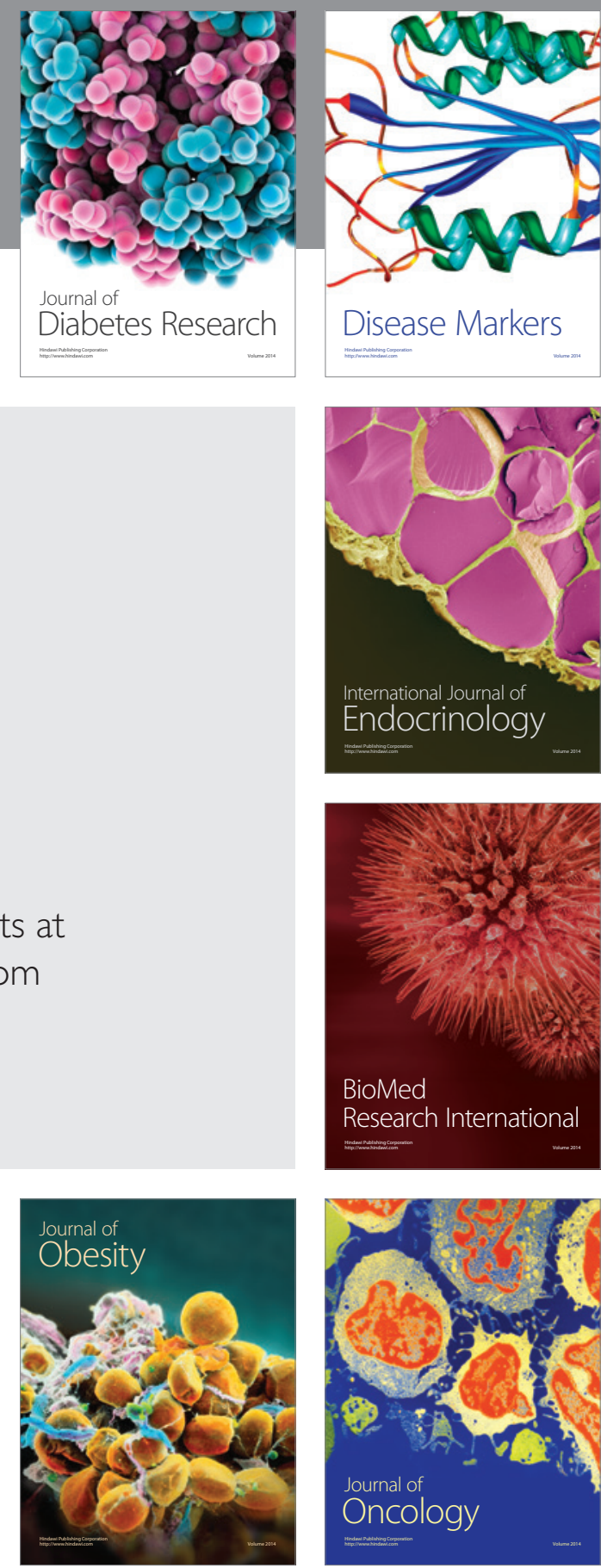

Disease Markers
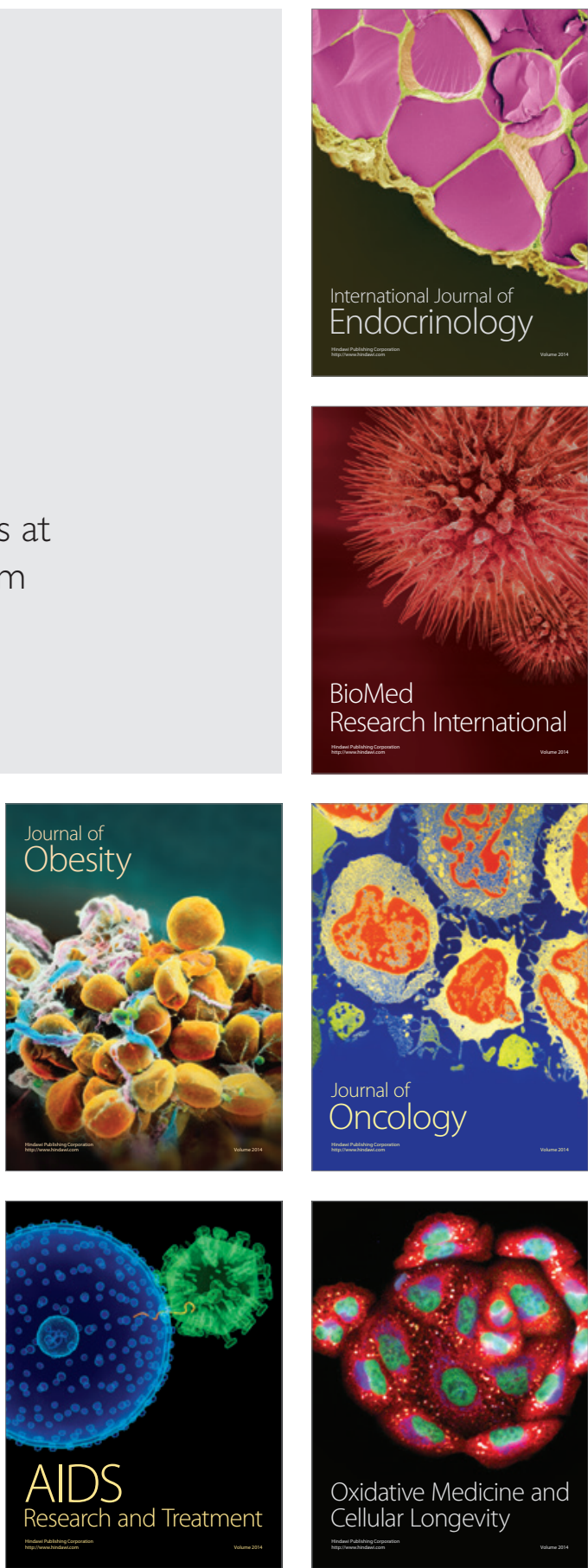